LBNL-57319

\title{
Financing the Growth of Energy Efficiency Service Industry in Shanghai
}

\section{Introduction}

In 2002, the government of Shanghai has identified the development of a local energy efficiency service industry as a critical tool to improve the energy efficiency of Shanghai economy and reach its sustainable development goal for the city. It has sought technical assistance from the Lawrence Berkeley National Laboratory through existing collaborations on energy efficiency. In September 2003, several government agencies (such as the Shanghai Economic Commission) and LBNL jointly sponsored an international conference to present experiences of energy service industrial development in other countries (Lin et al, 2004).

In order to better understand key barriers to the development of energy efficiency service industry, a series of interviews was held with relevant stakeholders in Shanghai in August 2004, including those representing energy management companies (EMCs), banks, insurance companies, and government officials. These interviews identified several problems that have hindered the development of an energy efficiency service industry in Shanghai. One major problem is the lack of a viable financing system that can service all of the available energy efficiency projects. This paper will summarize the problem of project financing, show how that problem is similar to the problems faced by the ESCO industry in the United States (US) in the late 1980s, and describe the way the US ESCO project finance system evolved. The authors hope that some of these experiences from the US may be useful to the Shanghai regional government in its effort to spur the development of a local energy efficiency service industry.

\section{Problem: Financing Projects is Difficult}

The interviews documented the fact that it is very difficult for ESCOs in the Shanghai region to obtain adequate financing for their projects. Adequate financing can be defined as financing that will allow the ESCO to install all cost-effective measures at a customer's facility and repay the cost of the measures (materials, labor, engineering design, construction supervision, etc.), plus a reasonable profit for the ESCO, out of the savings produced by the measures. The customer should have to pay little or nothing in a cash down payment, but should be able to finance the project from the savings. The availability of adequate financing for ESCOs is dependent on the willingness of banks and other organizations to lend money for ESCO projects. 


\subsection{Banks are reluctant to lend to customers}

At the present time, however, the banks in the Shanghai region are reluctant to lend money for ESCO projects, for several reasons that are described below.

\section{Banks don't understand energy-saving technologies}

The banks typically do not understand the energy-saving technologies that are installed in ESCO projects, and do not believe the claims of the ESCOs that the technologies will save enough money to repay their cost in a few years. Simply put, it is hard for a banker to believe that a new fluorescent lighting system can produce better light while using only half of the electricity of an older fluorescent system.

\section{No accepted measurement standard for savings}

The difficulty that the bankers have in believing the claims for energy-saving technologies is compounded by the lack of a clearly-defined and generally accepted system for measuring and verifying the savings produced by energy-saving technologies. Each ESCO a banker talks to seems to have its own system for measuring savings, based on engineering data and complex calculations that are mysterious to the bankers.

\section{Banks make only asset-based loans}

If a banker can understand the technologies and understand the ESCO's method of measuring and verifying savings, the next problem is the lack of a tangible asset which can serve as security for a loan. A typical ESCO project involves the installation of many energy-saving measures, such as lighting fixtures, which would be difficult for a bank to re-possess, and would have little re-sale value, if the customer were to fail to repay the loan. Banks are used to lending money on a piece of property, or a large piece of capital equipment. Many ESCO projects do not have such capital assets, and so banks see nothing to lend against.

\section{Customers have limited credit histories}

Another problem is that because of the very fast growth of the economy in the Shanghai region, many of the potential customers for ESCO projects are new companies. They have not been in business long enough to have the kind of predictable profits and cash flows that bankers like to see. The customers also have limited histories borrowing and repaying loans to banks (credit histories), so the banks view these customers as risky.

\subsection{ESCOs must borrow to finance projects}

If the banks are unwilling to lend to customers, the only available option is for the ESCOs to borrow the money themselves to finance the projects. This option, however, has a very limited scope, for two reasons.

\section{ESCOs have limited borrowing capacity}

ESCOs have a very limited capacity to borrow to finance projects because they are small, young companies with weak balance sheets. A bank is typically willing to lend to a company like an ESCO based on a formula of debt to equity. For example, a bank might be willing to lend an ESCO 70\% of the value of its tangible assets. Thus, a typical ESCO 
is not able to borrow enough money to grow its business aggressively, because aggressive growth would require loans equal to several times its tangible assets.

\section{Loans to ESCOs are short-term (mostly 1 year)}

The limited borrowing capacity of ESCOs is further limited by the fact that banks typically treat the loans to ESCOs not as term loans, but rather as working capital loans. A term loan typically requires that the borrower repay the loan in installments over a period of years. Using a term loan, an ESCO could install measures in a customer's facility that pay for themselves in three years, and finance the project with a four-year loan. A working capital loan, however, typically has to be fully repaid within one year. Using this type of financing, an ESCO either has to install a project which can repay its cost in less than a year, or find some sort of "bridge" financing that will allow the ESCO to fully repay the working capital loan for a week or two, and then re-borrow the working capital loan for another year. This is a very difficult way to finance a business, which only a few ESCOs can be expected to master.

\section{How US ESCOs Overcome Similar Problems}

The financing problems faced by the ESCO industry in the Shanghai region are very similar to the financing problems faced by the US ESCO industry in the late 1980s and early 1990s.

\section{Banks were unwilling to lend to ESCO projects}

US banks were unwilling to lend to US ESCO customers for the same reasons that the Shanghai banks are unwilling to lend to Shanghai customers. US banks did not understand the energy-saving technologies, did not believe the claims the ESCOs made about savings, and did not see any reliable method for measuring and verifying savings.

\section{Commercial and industrial customers were hard to finance}

Though many US ESCO customers had longer credit histories than the customers of Shanghai ESCOs, they were very difficult to finance for other reasons. Industrial customers typically expected a very short payback on energy savings projects, negotiated very hard to cut the prices charged by ESCOs, and then tried to do the project without the ESCOs whenever possible. Commercial customers typically had already mortgaged their properties to their full value, and had no remaining borrowing capacity to use to finance an energy-saving project.

Because of the reluctance of the banks to lend and the difficulty of financing industrial and commercial customers, the US ESCO industry struggled for about ten years. Many observers predicted that the ESCO industry would not survive, because the task of developing a viable project financing system was impossible.

Fortunately, the observers who predicted the early death of the US ESCO industry were wrong. The US ESCO industry developed a viable financing system that has enabled it to grow and prosper during the last decade. Some of the innovations that were developed in the US, which are described below, may be useful to the Shanghai government. Readers of this section are asked to remember that the banking industry can adopt an innovation very quickly. Unlike other industries that require major capital investments in research, raw materials or manufacturing 
equipment, banks require only money and innovative risk management tools to launch a new product. When one bank develops a new product, such as an ESCO project loan, and demonstrates that the new product can make money, other banks can adopt the new product very quickly. There is no need to wait for engineers to perfect new manufacturing processes, or for equipment vendors to deliver a new production lone. Capital will flow into the new product so fast that the problem for the government quickly becomes controlling the flow to prevent the market from overheating.

\section{Successful Financing Solutions}

In the US, other types of companies (not banks) provided ESCO project financing initially. Three types of companies are described below. Note that two of the three example companies are utility subsidiaries. Utilities became ESCO project financiers because they were ordered by regulators to pay incentives for ESCO projects under the demand-side management program (DSM), and they wanted to capture some of the profits from the ESCO business, which they believed would be a major trend in the US.

\section{An ESCO parent company financed projects}

One company that provided ESCO financing was the utility parent company of an ESCO. The ESCO had actually started as an independent company, and was purchased by the utility because the utility saw the potential growth in the ESCO business. The utility used its balance sheet to borrow money to finance ESCO projects, and lent the money to the ESCO projects at very high rates (15-25\%) all across the US. The customers were willing to finance projects at these rates because they were getting part of the cost of the projects paid for by the local utilities (see discussion below), so the net cost to them was reasonable. At one point, about $25 \%$ of the earnings of the utility came from its ESCO subsidiary. The utility exploited the opportunity until the banks got into the business, and then sold its ESCO.

\section{A utility established a subsidiary to finance small projects}

A second company was established by a utility especially for the purpose of providing financing for smaller ESCO projects in its service territory. The utility saw that the smaller ESCOs could not finance their projects, and set up a company that provided both project financing and project savings measurement and verification $(\mathrm{M} \& \mathrm{~V})$. The utility made money on the spread between its cost of borrowing ( 9\%) and the rate at which it could lend to the projects (15-20\%) as well as on its M\&V services. The utility exploited this opportunity until the banks got into the business, and then shut down its financing subsidiary.

\section{A property developer established an ESCO financing subsidiary}

A third company was established by a major regional property developer to finance large ESCO projects. The property developer had implemented some ESCO projects in its properties, and so understood the business. It provided an ESCO-friendly lending service, which relieved the ESCOs of having to go through the difficult process of selling projects to banks, and also relieved the ESCOs of the long-term M\&V responsibilities for their projects. This company used a real estate leverage model (very high debt to equity ratios) to deliver high returns to its investors, and was eventually sold to ABB. 


\section{Other Enabling Factors}

\section{The development of the IPMVP}

In the early 1990s, the National Association of Energy Service Companies (NAESCO), the American Society of Heating, Refrigeration and Air Conditioning Engineers (ASHRAE) and other parties saw the need for a standardized methodology for measuring and verifying the energy savings produced by an ESCO project. They established a working group that developed what is now called the International Performance Measurement and Verification Protocol (IPMVP, available at www.ipmvp.org), which is widely accepted by both customers and banks as the definitive protocol.

US banks saw that the specialty ESCO project finance companies described above were very profitable, and saw that the IPMVP made it possible to reliably predict and measure the energy savings from an ESCO project. In the mid-1990s, they began to establish small business units to develop the ESCO business. These business units developed innovative financing products that substantially reduced the cost of project financing from the prices charged by the specialty companies. Major international banks such as Citibank, GE Capital and ABN Amro, as well as regional banks and specialty ESCO project financing brokers aggressively compete with each other to provide financing for ESCO projects. Today, this private ESCO project financing market provides several billions dollars of financing each year. It is constantly innovating new products, but is subject to the review of regulators who ensure that the new products deliver what they promise and conform to accounting and tax regulations.

\section{Shared savings to guaranteed savings}

One of the major innovations that the banks introduced was to help ESCOs transition from shared savings to guaranteed savings project financing. In the US, as in Shanghai, shared savings financing dominated the early years of the ESCO industry. In a shared savings project, the ESCO borrows the money to finance the project, and shares the savings with the customer. The customer's only obligation is to allow the ESCO to capture most the value of the energy savings. The customer's risk is relatively small, but the cost of financing is relatively high. As customers learned that energy savings technologies are really not very risky, both customers and ESCOs resisted paying the high costs of shared savings financing. So they pushed the banks to provide loans directly to the customers, who could generally borrow at lower rates than the ESCOs, with a guarantee from the ESCO that the project would produce enough savings to repay its cost. Thus, the interest cost of project financing has fallen from the range of $15-25 \%$ that characterized the early specialty financing companies to the range of $4-9 \%$ today.

\section{ESCOs concentrated on public sector projects}

Another very significant development in the US ESCO business that made project financing easier was that ESCOs shifted their business focus from the private to the public sectors, the so-called MUSH markets (municipals, universities, schools and hospitals). ESCOs learned that the MUSH markets typically have much longer project payback horizons than private-sector commercial and industrial customers, which makes it possible for the ESCO to develop larger projects. MUSH market projects are usually 
much easier to finance, because bankers think that government customers are much more stable and thus better credit risks than commercial and industrial customers.

\section{Utilities provided incentives to commercial and industrial customers}

Another factor in the development of the ESCO project financing business in the US was the financial incentives offered by utilities to promote ESCO projects in the facilities of their industrial and commercial customers. As discussed above, in the US it was hard for the ESCOs to finance industrial and commercial projects. The resistance of commercial and industrial customers to implementing energy savings technologies became known as "market barriers", that is, problems that the competitive market was unable to solve on its own. Federal and state government energy planners and regulators saw these market barriers and also saw that the US electricity industry had reached an impasse. Both large fossil-fuel steam generating plants and nuclear power plants had reached a scale at which they exhibited significant technological problems, and no longer exhibited decreasing economies of scale. Public pressure also made new energy facilities, both generating plants and transmission lines, increasingly difficult to site.

So the state government energy policy planners and regulators instituted what they called "Integrated Resource Planning” (IRP), which compelled utilities to look at a full range of resources that might meet their increasing power requirements of their customers. In addition to the traditional, utility-owned large central station power plants, utilities had to examine options, such as buying power from smaller plants developed by private owners, or providing incentives to customers to implement energy-saving technologies. Utilities had to rank order the resource alternatives and purchase the lowest cost resources first. Not surprisingly, energy efficiency was in many cases the lowest priced resource, so utilities established programs to procure those resources by paying customers to implement energy-saving technologies at their facilities. An example was the state of New Jersey, which established a program to procure what it called an "Energy Efficiency Power Plant” from utility customers. From 1993-1998, one New Jersey utility procured 300 megawatts of energy savings in the form of ESCO projects from its customers by paying virtually the whole cost of the projects. The state of New Jersey compelled this program because paying the full cost of the ESCO projects was less expensive than building new power plants.

This type of program became very popular across the US, so that by the mid-1990s, US utilities were spending almost $\$ 2$ billion per year to acquire energy efficiency resources from their customers. Utility spending decreased during the late 1990s and early 2000s, when the US electricity industry was partially de-regulated, on the theory that the market would do a better job of acquiring the necessary resources than a government planning process. The market, however, has failed to perform. Many states are returning to the IRP process, and utility spending for energy efficiency resources is growing again. 


\section{Lessons from the US that might be useful in Shanghai}

The authors believe that several of the lessons learned in the development of the US ESCO project financing industry might be useful to the Shanghai government and therefore make the following recommendations.

\section{Try a variety of approaches simultaneously}

The development of the US ESCO project financing industry was dependent on several approaches that proceeded simultaneously, including:

- Willingness of non-banks, particularly utilities, to provide ESCO project financing because they could make high profits for a few years;

- Setting aside part of the DSM portfolio of incentives to support ESCO projects and the growth of the ESCO industry; and,

- Concentration of the ESCOs on public sector projects, because the customers are more stable and the projects are easier to finance.

\section{Adopt and adapt the IPMVP}

The development of ESCO project financing in the US was significantly accelerated by the introduction of the IPMVP, which reassured bankers that the energy savings from projects could be measured and verified using standardized and transparent protocols. The IPMVP could be very quickly adopted by the Shanghai government as the standard, with appropriate adaptations for local technologies and engineering practices, at virtually no cost ${ }^{1}$.

\section{Concentrate on finding one company willing to make ESCO project loans}

The US experience was that the one company (the ESCO subsidiary described above) basically got the ESCO project finance industry started in the US, by demonstrating to other potential financiers that the business could be profitable with a controllable risk. The authors believe that a single, aggressive finance company could have the same effect on the Shanghai region. This innovative company need not be a bank, and in fact probably won't be a bank. Rather it will be a utility, or a property developer that understands the energy efficiency technologies and can manage risk.

\section{Get maximum leverage from the World Bank guarantee funds}

The authors' understanding is that the World Bank guarantee program is currently operated from an office in Beijing, which makes it difficult for ESCOs in the Shanghai region to access. It would be useful if the guarantee fund could have an office in Shanghai. It would be better if the guarantee fund could be used to leverage private resources, by, for example, providing the bridge funding required to roll over successful ESCO projects that are funded by working capital loans. If resources are available, the government of Shanghai might consider working with local banks or financial

\footnotetext{
${ }^{1}$ IPMVP is being translated in to Chinese and should be available soon.
} 
intermediaries to develop these types of funding mechanisms. Particular attention should be paid to providing incentives for the employees of local banks and financial intermediaries to actually make loans to good ESCO projects. Employees often think that they are protecting the interests of the bank by turning down new types of loans, or loans to newer companies. A carefully constructed program of incentives can encourage employees to do the extra work required to understand the new loans and new companies, and so complete the financing that will be required to enable the ESCO industry in Shanghai to grow. 


\section{Reference}

Goldman C, Hopper N, Osborn J, and T Singer, 2005, "Review of US ESCO Industry Market Trends: A Empirical Analysis of Project Data,” LBNL-52320, Berkeley, California.

Hopper N, Goldman C, and Birr D, 2004, “The Federal for ESCO Services: How Does It Measure Up.” LBNL-54952. Berkeley, California.

Hopper N, Goldman C, Williams J, Birr D, and Stoughton KM, 2005, “Public and Institutional Market for ESCO Services: Comparing Programs, Practices, and Performance.” LBNL-55002. Berkeley, California.

IPMVP, International Performance Measurement and Verification Protocol, www.ipmvp.org

Lin J, Goldman C, Levine M, and Hopper N, 2004, "Developing an Energy Efficiency Service Industry in Shanghai.” LBNL-54964, Berkeley, California.

Zhao YH, 2004, research note on Shanghai energy management companies. 